\title{
A barrier to upstream migration in the fish passage of Itaipu Dam (Canal da Piracema), Paraná River basin
}

\author{
Hélio Martins Fontes Júnior ${ }^{1}$, Theodore Castro-Santos², Sergio Makrakis ${ }^{3}$, \\ Luiz Carlos Gomes ${ }^{4}$ and João Dirço Latini ${ }^{4}$
}

The majority of the fish passages built in the Neotropical region are characterised by low efficiency and high selectivity; in many cases, the benefits to fish populations are uncertain. Studies conducted in the Canal da Piracema at Itaipu dam on the Parana River indicate that the system component designated as the Discharge channel in the Bela Vista River (herein named Canal de deságue no rio Bela Vista or CABV), a $200 \mathrm{~m}$ long technical section, was the main barrier to the upstream migration. The aim of this study was to evaluate the degree of restriction imposed by the CABV on upstream movements of Prochilodus lineatus and Leporinus elongatus, Characiformes. Fish were tagged with passive integrated transponders (PIT tags) and released both downstream and upstream of this critical section. Individuals of both species released downstream of the CABV took much more time to reach the upper end of the system (43.6 days vs. 15.9 days), and passed in much lower proportions $(18 \%$ vs. $60.8 \%)$ than those tagged upstream of this component. Although more work is needed to differentiate between fishway effects and natural variation in migratory motivation, the results clearly demonstrate passage problems at the CABV.

A maioria dos sistemas para transposição de peixes implantados na região Neotropical caracteriza-se por baixa eficiência e seletividade, em muitos casos com benefícios questionáveis para as populações de peixes. Estudos conduzidos no Canal da Piracema, localizado na barragem de Itaipu, rio Paraná, apontaram como principal barreira à migração ascendente o componente do sistema denominado Canal de deságue no rio Bela Vista (CABV), uma seção de escada com $200 \mathrm{~m}$ de extensão. Este estudo teve por objetivo avaliar o grau de restrição imposto pelo CABV aos movimentos ascendentes de Prochilodus lineatus e Leporinus elongatus, Characiformes. Os peixes foram marcados com Passive Integrated Transponders (PIT-tags) e soltos a jusante e a montante do CABV. Indivíduos de ambas as espécies de jusante do CABV levaram muito mais tempo para atingirem a extremidade superior do sistema (43,6 dias vs. 15,9 dias) e passaram em muito menor proporção (18\% vs. 60,8\%) do que os marcados a montante desse componente. Embora sejam necessários outros trabalhos para a distinção entre os efeitos do sistema de transposição de peixes e a variação natural da motivação migratória, os resultados demonstram claramente que existem problemas na passagem pelo CABV.

Key words: Fish migration, Nature-like, Neotropical fishes, PIT-tag, Telemetry.

\section{Introduction}

The Paraná River and its principal tributaries have been impounded by multiple hydroelectric dams. This has converted a once free-flowing river to an extensive cascade of highly regulated reservoirs. This has caused a dramatic alteration in the hydrograph, most notably through the attenuation of flood peaks. The presence of these dams has been particularly damaging to populations of migratory fishes, which can suffer from fragmentation of populations. In addition to the barriers themselves, the combined effects of inundated reservoirs and flow regulation reduce or prevent access to important habitats for spawning, growth, and initial development (Agostinho et al., 2007).

Managers and engineers have attempted to mitigate the effects of dams on migratory fish species by building fish

\footnotetext{
${ }^{1}$ Usina Hidrelétrica de Itaipu. Divisão de Reservatório - MARR.CD. Av. Tancredo Neves, 6731. 85856-970 Foz do Iguaçu, PR, Brazil. hfontesjunior@gmail.com

${ }^{2}$ USGS-S.O.Conte Anadromous Fish Research Center. Leetown Science Center. Turners Falls, MA 01376. tcastrosantos@usgs.gov ${ }^{3}$ Universidade Estadual do Oeste do Paraná, Grupo de Pesquisa em Tecnologia de Produção e Conservação de Recursos Pesqueiros e Hídricos (GETECH), Programa de Pós-Graduação em Recursos Pesqueiros e Engenharia de Pesca. Rua da Faculdade, 645, Jardim Santa Maria, 85903-000 Toledo, PR, Brazil.makrakis@terra.com.br

${ }^{4}$ Universidade Estadual de Maringá - NUPELIA. Av. Colombo, 5790. 87020-900 Maringá, PR, Brazil. 1cgomes@nupelia.uem.br, latinijd@nupelia.uem.br
} 
passages, such as ladders, locks, migration channels and elevators (Larinier, 2002a, 2002b). Despite several attempts to evaluate these fish passages summarized in a special volume of Neotropical Ichthyology (2007, volume 5, number 2), there is still a very limited understanding of how migratory species use these fish passages, and there are many doubts regarding their efficiency, particularly in the Neotropical region (Agostinho et al., 2002; Agostinho et al., 2008).

The reach of the Paraná River between the Itaipu reservoir and the dams of Rosana and Porto Primavera (UHE Eng. Sérgio Motta-CESP), represents the last remaining lotic reach of this watershed in Brazilian territory, with important potential for the maintenance of the potamodromous population species (Agostinho et al., 2000). The tributaries of the Itaipu reservoir and the floodplain of the upper Paraná River, upstream of this reservoir, are very important for reproduction of migratory species (Agostinho et al., 1993). It was observed that at least six of the ten most frequently fished species in the reservoir complete their life cycle in the upstream part of the basin (Agostinho et al., 2004; Okada et al., 2005).

The Bela Vista River is the main section of the Canal da Piracema at Itaipu Dam that with the technical fish passage section contains the only large-scale partially nature-like fish passage in South America (Fig. 1; Agostinho et al., 2007). Designed to mimic natural stream channels, the nature-like fish passages are widely thought to provide superior passage performance for a wide range of species and life stages (Wildman et al., 2002). These claims are largely unsubstantiated, however, and in many cases they perform no better (or even worse) than more technical designs (Bunt et al., 2011). The monitoring of the Canal da Piracema began in 2004, with the collection of data from its diverse segments (mainly with gill nets and circular casting nets), and with radiotelemetry. Data on the captures determined that fishes of diverse migratory species use the Canal da Piracema during their migratory phase (Fontes Jr., pers. comm.). Although individuals of some species successfully pass the Canal, available data suggest that passage may be poor (Hahn, 2007; Makrakis et al., 2011), and the system component designated as the Discharge channel in the Bela Vista River (herein named Canal de deságue no rio Bela Vista or CABV), a $200 \mathrm{~m}$ long technical section, was the main barrier to the upstream migration. Although detailed data are lacking for other systems, low fish ascension efficiency coupled with species selectivity appears to be a common characteristic of South American fish passages (Oldani \& Baigún, 2002; Agostinho et al., 2002, 2007; Makrakis et al., 2007a; Godinho \& Kynard, 2009). However, the fish pass efficiency for South American rivers must consider its capability to maintain viable populations (Pompeu et al., 2012).

Fish passage evaluation by PIT telemetry is gaining popularity (Castro-Santos et al., 1996; Aarestrup et al., 2003; Teixeira \& Cortes, 2007) and it can be a highly effective and low-cost methodology for studying movements of fishes of varying sizes and morphologies (Prentice et al. 1990; Franklin et al. 2012). It is particularly useful for quantifying movements through confined structures like fish passages (Castro-Santos et al., 1996). Like other telemetry methods, PIT telemetry can provide continuous monitoring at fixed locations, which allows for evaluation of the environmental factors (e.g., water temperature and flow rate) on movement and passage success (Lucas \& Baras, 2000). Here, we present one such study designed to verify and improve our understanding of the degree of restriction imposed by the Canal de deságue no rio Bela Vista (CABV) on upstream migrating fishes. The objectives of this study were to evaluate the degree of restriction imposed by the CABV on upstream movements of Prochilodus lineatus (Valenciennes, 1837) and Leporinus elongatus (Valenciennes, 1850), Characiformes, and to verify their movements in the Canal da Piracema technical sections. The aim of this study was to test the hypothesis that the CABV represents a barrier to the ascent of fishes in the Canal, by delaying their movement.

\section{Material and Methods}

\section{Study area}

The Canal da Piracema is a fish passage located adjacent to the Itaipu Hydroelectric Power Plant, Paraná State, Brazil. The system is intended to reconnect the Paraná River, downstream of the Dam with the Itaipu reservoir, surmounting a difference in water level of 120 metres. The Canal da Piracema comprises two large subsystems. The lower section ("naturelike reach') is a nature-like fish passage, being constructed within the original streambed of the Bela Vista River and Brasília Stream. The upper section ('technical reach') comprises several technical designs, including multiple ladders, channels, and lakes of various designs and dimensions, connecting the nature-like section with the Itaipu reservoir (Fig. 1).

The nature-like reach, with a length of approximately 6.7 $\mathrm{km}$, represents $2 / 3$ of the total length of the system and $57.5 \mathrm{~m}$ elevation gain ( $48 \%$ of total), with the Bela Vista River as its principal component. This river originally possessed a broader catchment basin, which was captured and inundated by the construction of the Itaipu dam in 1982. For the next 20 years its flow was reduced, draining only a watershed of modified land associated with the construction of the Itaipu project (Fig. 1). When the Canal da Piracema was built in 2002, the flow in the Bela Vista River was once more increased by more than 20 times.

The technical reach begins (from the downstream end) in the original Brasília streambed, approximately $850 \mathrm{~m}$ upstream of its confluence with the Bela Vista River. The first component of this subsystem is a structure called the Canal de deságue no rio Bela Vista (CABV), with a length of $200 \mathrm{~m}$, width of $5 \mathrm{~m}$, height of $2.5 \mathrm{~m}$ and a difference in levels of $12.5 \mathrm{~m}$, that results in a gradient of $6.25 \%$. The CABV is fitted with 38 deflectors of reinforced concrete, spaced 4 metres for each other, forming a section of ladder steps with a turbulent flow.

The CABV drains the Lower Lake (herein named Lago inferior or LAIN), with an area of 1.2 ha and a maximum depth 


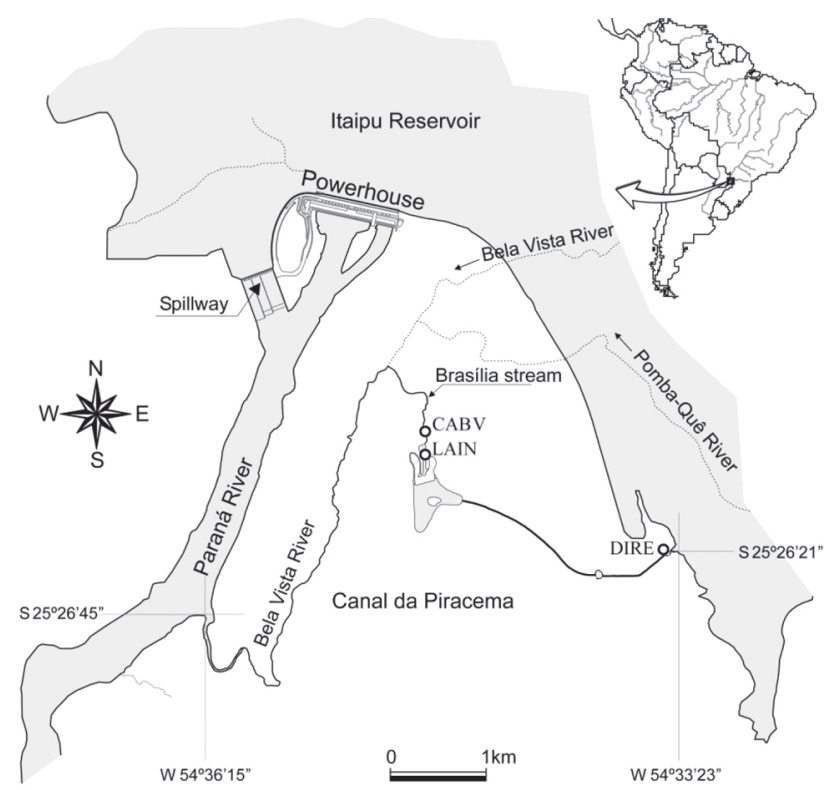

Fig. 1. The Canal da Piracema and its components mentioned in this study: nature-like subsystem (Bela Vista River and Brasilia stream); CABV - Canal de Deságue no rio Bela Vista, LAIN - Lago Inferior; DIRE - Dique de Regulagem

of $2 \mathrm{~m}$, which is fed by the several technical designs of the upper sections (Fig. 1). In the water intake area there is the Control Dike (herein named Dique de regulagem or DIRE), situated at the very end of the earthen dam of the Itaipu Reservoir. For a detailed description of these components consult Fiorini et al. (2006) and Makrakis et al. (2007b, 2011). Physical characteristics of the canal differed among sections. Mean water velocities were highest in the sections comprising the Bela Vista River and the CABV, with means ranging 1.4$1.7 \mathrm{~m} \mathrm{~s}^{-1}$, and less than $1 \mathrm{~m} \mathrm{~s}^{-1}$ in the upper sections upstream of the CABV. Similarly, maximum velocity was greatest in the lower sections with values over $1.8 \mathrm{~m} \mathrm{~s}^{-1}$ and a record high 3.2 $\mathrm{m} \mathrm{s}^{-1}$ in a small section of the Bela Vista River (this point has no obstacles to reduce water velocity, such as the deflectors in the technical sections) (Makrakis et al., 2011). The hydraulic characteristics of the Canal also include a minimum depth of $0.8 \mathrm{~m}$ and minimum transversal passage area of approximately $5 \mathrm{~m}^{2}$. Based upon hydraulic calculations and model tests, the flow that fulfils the conditions for the migratory species is about $11.4 \mathrm{~m}^{3} \mathrm{~s}^{-1}$. This condition has been shown good to attract fish and provide migration along the whole system.

\section{Telemetry}

The PIT-tag system (or as it is often called, a Radio Frequency Identification, or RFID system) used in his study was the TIRIS S 2000 system (Castro-Santos et al., 1996; Zydlewski et al., 2001; Haro, 2002). The PIT telemetry has been used to monitor the movement of migratory species in the Canal da Piracema since December 2009.
Three pass-through antennas were installed for this study, each of $2.0 \times 1.2 \mathrm{~m}$, in the Dique de regulagem (DIRE) at the upper end of the system, at a distance of approximately 3,500 $\mathrm{m}$ from the area where the fishes were tagged and released. The DIRE is part of the intake area of the Canal da Piracema and it has three gates to control water flow in the system. The antennas were placed into wood structures which were fixed on the bottom and walls of the gates housing.

Overall transit time and passage success was measured from the CABV to the DIRE as elapsed time from release to first detection at the DIRE. In order to differentiate between passage through the $\mathrm{CABV}$ and passage through upstream sections, fish were released from two locations, upstream and downstream of the CABV. Passage performance through the CABV was estimated as the difference in percent passage and transit time between the upstream- and downstreamreleased groups.

\section{Data collection}

In the period from December 8, 2009 to February 26, 2010, 219 individuals of two migratory species (181 Prochilodus lineatus, mean total body length $54 \mathrm{~cm}$, range $39.5-70.0 \mathrm{~cm}$, and 38 Leporinus elongatus, mean total body length $53.5 \mathrm{~cm}$, range $40.5-64.5 \mathrm{~cm}$ ) were tagged. Of these, 91 P. lineatus and 26 L. elongatus were caught and released in the Bela Vista River and the Brasília stream (downstream of the CABV or downstream release group), and $90 P$. lineatus and 12 L. elongatus were caught and released in the Lago Inferior (LAIN), upstream of the CABV or upstream release group (Fig. 2). These species are abundant at Canal da Piracema, where they were captured using a circular casting net.

All fish were anaesthetized with eugenol, measured (total length and standard length), and tagged surgically by implanting $32 \mathrm{~mm}$ transponders using a No. 15 scalpel blade. The insertion was on the abdomen of the fish to the right or left of the midventral line and between the tips of the pleural ribs. No suture or glue was needed. The time of induction and recovery were about one and three minutes respectively. PIT data were logged using custom software that interfaced with the PIT system and recorded tag number, location, and time to the nearest $0.01 \mathrm{~s}$ (CastroSantos, 2000).

\section{Data Analysis}

Transit times were measured as the time elapsed between the release time and the first observation on the PIT system at DIRE. Percent passage was calculated for each species as number detected by the PIT system divided by the number released. The data were presented evaluating the ascent (in percentages) for the species tagged. To evaluate the ascension probabilities of fish in the Canal da Piracema, we used a survival analysis (Allison, 2010). The use of survival analysis helps to detect which parts of the fish passage hinders the passage or even impedes fish ascension (CastroSantos \& Haro, 2003; Castro-Santos, 2004; Haro et al., 2004; 




Fig. 2. Locations of capture, tagging with the PIT and release of individuals of Prochilodus lineatus and Leporinus elongatus in the Canal da Piracema.

Makrakis et al., 2007b). In this analysis, we used time of ascent as the response variable (event) determined by the time span between release and detection at the antenna (Haro et al., 2004; Makrakis et al., 2011). The time elapsed between the moment of release and the moment of passing through DIRE was measured, and estimates of 'survivorship' functions for the time elapsed were calculated using the Kaplan-Meier (SAS 9.3, 2010) of event-time analysis (Kaplan \& Meier, 1958; Allison, 1995; Castro-Santos \& Haro, 2003). Individuals tagged that didn't pass until the end of study were censored (type I censoring).

To test the difference between the groups (fish species and sites CABV and LAIN) checking the proportion passing and transit time we used the survivorship curves by applying the PROC LIFETEST (SAS 9.3, 2010) and analyzed the logrank and Wilcoxon statistics for each treatment group, followed by an estimate of their covariance matrix. The tests readily generalize to three or more groups, with the null hypothesis that all groups have the same survivor function. If the null hypothesis is true, the test statistics all have chi-square distributions with degrees of freedom equal to the number of groups minus 1.

The univariate procedure was applied to test for normality of data using SAS 9.3.

\section{Results}

Of the 219 fish released of both species, 83 (37.9\%) passed upstream through the system. Overall percent passage of $P$. lineatus was $41 \%$, with much greater passage among individuals released upstream of the CABV (62.2\%) compared with those released downstream of the CABV $(19.8 \%$, SAS logistic procedure $\mathrm{P}<0.001$; Table 1). Although the sample size was much smaller, a similar pattern was observed for $L$. elongatus: $50.0 \%$ passage for fish released upstream vs. $11.5 \%$ passage for those released downstream of the $\mathrm{CABV}(\mathrm{P}=0.015$; Table 1). Furthermore, during the monitoring in the Canal da Piracema, the RFID system suffered short random outages caused by the need to replace equipment (antenna, reader, computer) and power outages, but this may be small influence in the results because for the three downstream release groups (Dec 8, $2009 n=53$; Dec 23, $2009 n=50$ and Feb 26, $2010 n=15$ ) the percent passage were similar $(19 \%, 16 \%$ and $20 \%$, respectively). A more comprehensive description of passage performance is provided by comparing rates.

The reduction in passage success caused by the CABV appears to have been caused at least in part by increased delays incurred through that part of the fishway. Passage rates were far slower for downstream-released fish compared 
Table 1. Number of individuals marked with a PIT-tag downstream of the Canal de deságue no rio Bela Vista (CABV) and upstream (LAIN) and detected in the Dique de regulagem (DIRE). $\mathrm{TAG}=$ number of individuals tagged, $\mathrm{DET}=$ number of individuals detected.

\begin{tabular}{lcccccc}
\hline & \multicolumn{2}{c}{$\begin{array}{c}\text { Downstream } \\
\text { release group } \\
\text { and percent passed }\end{array}$} & \multicolumn{3}{c}{$\begin{array}{c}\text { Upstream } \\
\text { release group } \\
\text { and percent passed }\end{array}$} \\
\hline Species & TAG & DET & $\%$ & TAG & DET & $\%$ \\
\hline Prochilodus lineatus & 91 & 18 & 19.8 & 90 & 56 & 62.2 \\
Leporinus elongatus & 26 & 3 & 11.5 & 12 & 6 & 50.0 \\
\hline \multicolumn{1}{c}{ Total } & 117 & 21 & 18.0 & 102 & 62 & 60.8 \\
\hline
\end{tabular}

with upstream-released fish (Figure 3). The curves show that for both species the CABV acts as a barrier by reducing movement rate over time. Of the fish released in the LAIN that successfully passed the system, median passage time was 11 days, whereas median passage time for those released downstream of CABV was 36 days.

The chi-square tests of the null hypothesis that the survivor functions are identical across the four strata $(L$. elongatus $\mathrm{CABV}$, L. elongatus $\mathrm{LAIN}$, P. lineatus $\mathrm{CABV}$ and $P$. lineatus LAIN) were significant at the 0.05 level. Both the log-rank and Wilcoxon tests comparing downstream and upstream release groups were also significant (Allison, 2010).

\section{Discussion}

The results show that fish released downstream of the CABV took much longer to reach the DIRE in comparison with those released in the LAIN, supporting earlier observations that the CABV is the greatest bottleneck of the artificial subsystem (Hahn et al., 2007; Makrakis et al., 2007b, 2011). Substantial delays occurred above the CABV as well, however, significant barriers may exist even for fish that pass the CABV. The long migratory delay incurred at both of these sites could affect survival, especially if there are predators present within the Canal da Piracema. It could also influence reproductive viability for those individuals that do pass after passing the DIRE they still must negotiate a large impoundment, and they must do so while conditions remain appropriate for spawning. Although the effects of delays on spawning success have been widely hypothesized among north-temperate species (e.g. Chanseau et al., 1999; CastroSantos \& Haro, 2003), actual data demonstrating the problem are sparse. This largely reflects the difficulty of collecting the necessary data from individuals, however, in many cases there is sufficient knowledge about the importance of migration timing to reproduction and survival to justify the concern. Whether those same concerns are applicable to Neotropical migrants is an open question: unlike the temperate zones, where conditions vary widely and predictably, favourable conditions for spawning are much less predictable in the tropics, and it is possible that Neotropical migratory fishes have adopted strategies (e.g. feeding during

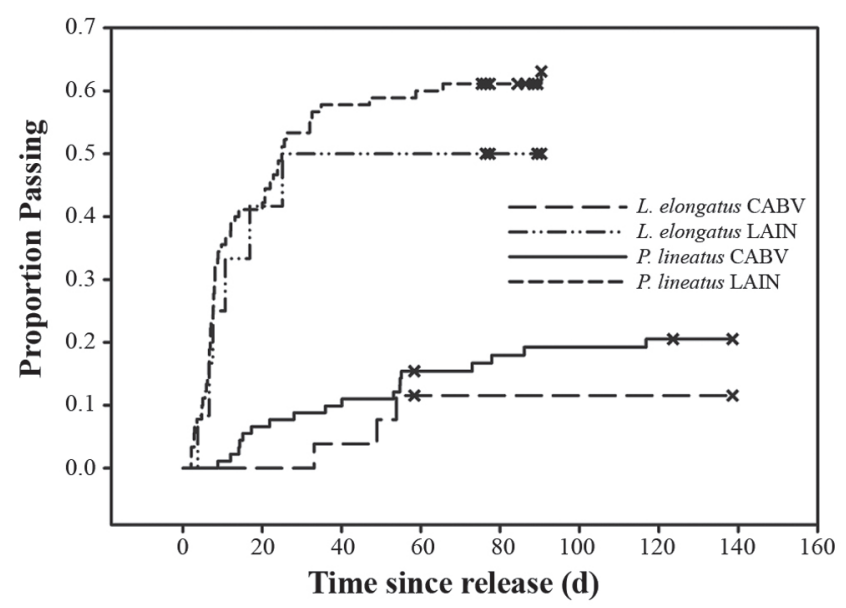

Fig. 3. Cumulative proportion passing the Canal de Piracema by species and release location. Curves are complements of survivorship functions calculated using the Kaplan-Meier method (Kaplan \& Meier, 1958). Censored observations are indicated by x's and represent the time elapsed between release and the last observed passage event for either species.

migrations) that allow for greater flexibility in the face of migratory delay. Further research is needed on life history and natural delays, in both tropic and temperate regions, to improve understanding of the importance of delay to reproductive success and survival.

Passage success through upstream fishways depends primarily on two factors: i) the capacity of the fishes to find and enter the system, and ii) the capacity of the fishes to pass through the length of the system (Aarestrup, 2003; Bunt et al., 1999, 2011; Castro Santos \& Haro, 2010). Although the efficiency of the Canal da Piracema has not been evaluated as a whole, various migratory species, but specially $P$. lineatus and L. elongatus are abundant in the Bela Vista River (Makrakis et al., 2007b). This may be result of the barrier represented by the $\mathrm{CABV}$ to the upstream migration. Apparently the design of the CABV (see description in Material and Methods) is not compatible with the swimming capability of $P$. lineatus that may find it difficult to overcome these conditions over $200 \mathrm{~m}$. Water velocity in the CABV reaches is less than $3 \mathrm{~m}^{3} / \mathrm{s}$, but the slope is the highest of the system, and may produce velocities in some zones that exceed swimming ability of some species. In addition, this zone is highly turbulent, which might pose both behavioural and physical barriers to movement (Martinez et al., 2001; Tritico \& Cotel, 2010). The swimming capacity of Brazilian fishes is an important parameter for dimensioning fish passages, although no fish passage yet built takes into consideration this important characteristic of the Neotropical species (Santos et al., 2007). Research in this area is recently being conducted in Brazil (Santos et al., 2007, 2008; Sampaio et al., 2009) and should constitute important references for new designs of fish passage systems and for the improvement of existing ones. The difference in the transit time to L. elongatus 
released downstream and upstream of the CABV was also significant. Although the number of individuals of this species tagged was lower than $P$. lineatus, the Figue 3 shows that the two species are very similar, and the added delay shows that retardation of movement, rather than a complete obstacle, can be the cause of the reduced passage for some individuals.

Results can have been influenced by the RFID system efficiency, mainly to $L$. elongatus with low number of individuals tagged. The efficiency of the stationary RFID system as used in this study was variable. Field studies using large PIT antennas have reported variable efficiency, ranging from $70 \%-100 \%$, depending on study and location (Zydlewski et al., 2001; Franklin et al., 2012). Despite this and the random outages, the current study demonstrated that at least $18 \%$ of the fishes tagged downstream of the CABV and $60.8 \%$ of the upstream release group, the majority being $P$. lineatus, reached the upper end of the transposition system. This number, besides still low to determine the success of a fish passage, is greater than previous estimates (Makrakis et al., 2007b, 2011), and shows that at least some $P$. lineatus, and also some $L$. elongatus are able to ascend the fish passage. For the individuals tagged in the LAIN, at least $50 \%$ of $L$. elongatus and $62.2 \%$ of $P$. lineatus were able to reach to DIRE. This result approaches those obtained by the use of radiotelemetry, which observed an efficiency of $30.1 \%$ of the fish released in the LAIN (Hahn, 2007). It is important to recognize that this is an underestimate of the percent passage, considering that the behaviour of the migratory species is determined by variables made manifest over a large temporal scale. In addition to this, the illegal fishing in the area (certified in $20 \%$ of the samples tagged with radio-transmitters) (Hahn, 2007), as well as the hydraulic and environmental conditions, affect the efficiency of the fish passages, whose results can vary greatly in experiments (Makrakis et al., 2011). All these factors possess the potential to hinder the interpretation of the data (CastroSantos et al., 1996; Castro-Santos \& Haro, 2003).

Although the passage estimate was biased low by equipment failures, passage times were long for both treatment groups. Even a conservative estimate suggests that the most numerous fish spent an average of 27 days passing just the CABV, and delay incurred throughout the system appears to have been sufficient to interfere with spawning and other life history events. More study is needed to better understand the magnitude of these delays and to provide better estimates of passage success through the various reaches of the Canal da Piracema, but the current study suggests that significant problems exist.

The motivation for the ascending movements can be diverse. For $P$. lineatus, that presented the largest rates of ascent, one must consider the possibility of a predominantly reproductive motivation, or of dispersal, since it is hardly likely that such an abundance observed of this species in the system could be related to the trophic stimulus, due to its illyophagous feeding habit and the apparently low availability of this type of food in the system. This was also verified by Makrakis et al. (2007a) in the fish ladder located in the Porto
Primavera, situated approximately $250 \mathrm{~km}$ upstream of the Itaipu reservoir. In that same hydro plant, Volpato et al. (2009), observed that $P$. lineatus individuals found in the upper part of the ladder were significantly larger than those found in the lower part, suggesting selectivity related to the size of the fishes. In the Canal da Piracema, however, the total length of the tagged $(39.5-70.0 \mathrm{~cm})$ and detected $(39.5-62.6 \mathrm{~cm})$ individuals did not show any evidence of selectivity in that range of sizes.

The PIT telemetry, despite the antennas cover only one section (DIRE) in the system, permitted identifying the delay in the movement of P. lineatus and L. elongatus due to the $\mathrm{CABV}$, which probably occurs with other species. However, the use of this technology in the Canal da Piracema should be further explored so that can be still possible to configure and install antennas in the CABV and other sections along the system. Meaningful evaluations of fish passage performance require that individual movements be monitored (CastroSantos et al., 2009; Bunt et al., 2011), ideally separating components of approach, entry, and passage (Bunt et al., 1999; 2011; Castro-Santos \& Haro, 2010), and explicitly quantifying passage performance in units of proportion of the available population passing per unit time (Castro-Santos et al., 2009). The current study has represented the first attempt to quantify passage rates, but more work is needed to integrate this information with the other elements of passage performance through this system.

The continuation of the monitoring and the installation of additional antennas along the length of the system will be of fundamental importance in the determination of the migratory movements and in the evaluation of the possible utilization of the mechanism as a seasonal dispersal route, or as a habitat for species that find favourable conditions for remaining in the system.

\section{Acknowledgments}

We thank Itaipu Binacional for financial and logistic support in this study. This article does not imply an assumption of responsibility by USGS.

\section{Literature Cited}

Aarestrup, K., M. C. Lucas \& J. A. Hansen. 2003. Efficiency of a nature-like bypass channel for sea trout (Salmo trutta) ascending a small Danish stream studied by PIT telemetry. Ecology of Freshwater Fish, 12: 160-168.

Agostinho, A. A., A. E. A. de M. Vazzoler, L. C. Gomes \& E. K. Okada. 1993. Estratificación espacial y comportamiento de Prochilodus scrofa em distintas fases del ciclo de vida, em la planície de inundación del alto rio Paraná y embalse de Itaipu, Paraná, Brasil. Revue D’Hidrobiologie Tropicale, 26: 79-90.

Agostinho, A. A., S. M. Thomaz, C. V. Minte-Vera \& K. O. Winemiller. 2000. Biodiversity in the high Paraná river floodplain. Pp. 89-118. In: Gopal, B., W. J. Junk \& J. A. Davis (Eds.) Biodiversity in Wetlands: assessment, function and conservation. Backhuys Publishers, Leiden, The Netherlands, 353p. 
Agostinho, A. A., L. C. Gomes, D. R. Fernandez, \& H. I. Suzuki. 2002. Efficiency of fish ladders for Neotropical ichthyofauna. River Research and Applications, 18: 299-306.

Agostinho, A. A., L. C. Gomes, S. Veríssimo \& E. K. Okada. 2004. Flood regime, dam regulation and fish in the Upper Paraná river: effects on assemblage attributes, reproduction and recruitment. Reviews in Fish Biology and Fisheries, 14: 11-19.

Agostinho, A. A., L. C. Gomes \& F. M. Pelicice. 2007. Ecologia e manejo de recursos pesqueiros em reservatórios do Brasil. EDUEM, Maringá, 512p.

Agostinho, A. A., F. M. Pelicice \& L. C. Gomes. 2008. Dams and the fish fauna of the Neotropical region: impacts and management related to diversity and fisheries. Brazilian Journal of Biology, 68: 1119-1133.

Allison, P. D. 2010. Survival Analysis Using SAS ${ }^{\circledR}$ : A Practical Guide, Second Edition. Cary, NC: SAS Institute Inc., 337p.

Bunt, C. M., C. Katopodis \& R. S. McKinley. 1999. Attraction and Passage Efficiency of White Suckers and Smallmouth Bass by Two Denil Fishways. North American Journal of Fish Migration, 19: 793-803.

Bunt, C. M., T. Castro-Santos \& A. Haro. 2011. Performance of fish passage structures at upstream barriers to migration. River Research and Application, 28: 457-478.

Castro-Santos, T., A. Haro \& S. Walk. 1996. A Passive Integrated Transponder (PIT) tag system for monitoring fishways. Fisheries Research, 28: 253-261.

Castro-Santos, T. 2000. Multireader 4.1. USGS S.O. Conte Anadromous Fish Research Center, Turners Falls, MA.

Castro-Santos, T \& A. Haro. 2003. Quantifying migratory delay: a new application of survival analysis methods. Canadian Journal of Fisheries and Aquatic Sciences, 60: 986-996.

Castro-Santos, T. 2004. Quantifying the combined effects of attempt rate and swimming capacity on passage through velocity barriers. Canadian Journal of Fisheries and Aquatic Sciences, 61: 1602-1615.

Castro-Santos, T., A. Cotel \& P. W. Webb. 2009. Fishway evaluations for better bioengineering - an integrative approach. Pp. 557-575. In: Haro, A. J., K. L. Smith, R. A. Rulifson, C. M. Moffit, R. J. Klauda, M. J. Dadswell, R. A. Cunjak, J. E. Cooper, K. L. Beal \& T. S. Avery (Eds.). Challenges for diadromous fishes in a dynamic global environment. American Fisheries Society, Symposium 69, Bethesda, MD.

Castro-Santos, T. \& Haro, A. 2010. Fish guidance and passage at barriers. Pp. 62-89. In: Domenici, P. \& B. G. Kapoor (Eds.). Fish Locomotion: An Eco-Ethological Perspective. Science Publishers, Enfield, NH.

Chanseau, M., O. Croze, \& M. Larinier. 1999. The impact of obstacles on the Pau River (France) on the upstream migration of returning adult Atlantic salmon (Salmo salar L.). Bulletin Francais de la Peche et de la Pisciculture, (353/354): 211-237.

Fiorini, A. S., D. R. Fernandez \& H. M. Fontes Jr. 2006. Itaipu Dam Piracema Migration Channel. Vingt Deuxième Congrès Des Grands Barrages. Proccedings, 325-348. Barcelona.

Franklin, A. E., A. Haro, T. Castro-Santos \& J. Noreika. 2012. Evaluation of nature-like and technical fishways for the passage of alewife (Alosa pseudoharengus) at two coastal streams in New England. Transactions Of the American Fisheries Society, 141: 624-637.

Godinho, A. L. \& B. Kynard. 2009. Migratory fishes of Brazil: life history and fish passage needs. River Research and Applications, 25: 702-712.
Hahn, L. 2007. Deslocamento de peixes migradores no rio Uruguai e no sistema misto de migração da barragem de Itaipu. Unpublished Ph.D. Dissertation, Universidade Estadual de Maringá, Maringá, 53p.

Hahn, L., K. English, J. Carosfeld, L. G. M. Silva, J. D. Latini, A. A. Agostinho \& D. R. Fernandez. 2007. Preliminary study on the application of radiotelemetry techniques to evaluate movements of fish in the lateral canal at Itaipu Dam, Brazil. Neotropical Ichthyology, 5: 103-108.

Haro, A. 2002. Manual for Operation of TIRFID PIT tag Systens. CAFRC - S. O. Conte Anadromous Fish Research Center, 19p.

Haro, A., T. Castro-Santos, J. Norelka \& M. Odeh. 2004. Swimming performance of upstream migrant fishes in openchannel flow: a new approach to predicting passage through velocity barriers. Canadian Journal of Fisheries and Aquatic Sciences, 61: 1590-1601.

Kaplan, E. L. \& P. Meier. 1958. Nonparametric estimation from incomplete observations. Journal of the American Statistical Association, 53: 457-481.

Kurt Steinke, P. E., J. Anderson \& K. Ostrad. 2011. Aquatic PIT tag Interrogation System Construction \& Standard Operating Procedure. USFWS - Abernathy Fish Technology Center - SOP Ecological Physiology Program, 62p.

Larinier, M. 2002a. Fishways - General considerations. Pp. 21-27. In: Larinier, M., F. Travade \& J. P. Porcher (Eds.). Fishways: Biological basis, design criteria and monitoring. Bulletin Français de la Pêche et de la Pisciculture, 364 suppl.

Larinier, M. 2002b. Biological factors to be taken into account in the desing of fishways, the concept of obstruction to upstream migration. Pp. 28-38. In: Larinier, M., F. Travade \& J. P. Porcher (Eds.). Fishways: Biological basis, design criteria and monitoring. Bulletin Français de la Pêche et de la Pisciculture, 364 suppl.

Lucas, M. C. \& E. Baras. 2000. Methods for studying spatial behavior of freshwater fishes in the natural environment. Fish and Fisheries, 1: 283-316.

Makrakis, S., M. C. Makrakis, R. L. Wagner, J. E. P. Dias \& L. C. Gomes. 2007a. Utilization of the fish ladder at the Engenheiro Sergio Motta Dam, Brazil, by long distance migrating potamodromous species. Neotropical Ichthyology, 5: 197-204.

Makrakis, S., L. C. Gomes, M. C. Makrakis, D. R. Fernandez \& C. S. Pavanelli. 2007b. The Canal da Piracema at Itaipu Dam as a fish pass system. Neotropical Ichthyology, 5: 185-195.

Makrakis, S., L. E. Miranda, L. C. Gomes, M. C. Makrakis, M. C. \& H. M. Fontes Jr. 2011. Ascent of Neotropical migratory fish in the Itaipu reservoir fish pass. River Research and Applications, 27: 511-519.

Martinez, C. B., J. Nascimento Filho, E. M. Faria \& M. G. Narques. 2001. Estudo de Monitorização de Mecanismos de Transposição de Peixes. 10p. IX Encuentro Latinoamericano y del Caribe sobre Pequeños Aprovechamientos Hidroenergéticos, Ciudad de Neuquen. IX ELPAH. Available from: www.cph.eng.ufmg.br/ docscph/prodgrupo28.pdf (28 May 2012)

Nielsen, L. A. 1992. Methods of Marking Fish and Shellfish. American Fisheries Society Special Publication, 23.

Okada, E. K., A. A. Agostinho \& L. C. Gomes. 2005. Spatial and temporal gradients in artisanal fisheries: a case study of the Itaipu Reservoir, Brazil. Canadian Journal of Fisheries and Aquatic Sciences, 62: 714-724.

Oldani, N. O. \& C. R. M. Baigún. 2002. Performance of a fishway system in a major South American dam on the Parana River (Argentina-Paraguay). River Research and Applications, 18: 171-183. 
Pompeu, P. S., A. A. Agostinho \& F. M. Pelicice. 2012. Existing and future challenges: the concept of successful fish passage in South America. River Research and Applications, 28: 504-512.

Prentice, E. F., T. A. Flagg \& S. McCutcheon. 1990. Feasibility of using implantable passive integrated transponder (PIT) tags in salmonids. Pp. 317-322. In: Parker, N. C., A. E. Giorgi, R. C. Heidinger, D. B. Jr. Jester, E. D. Prince \& G. A. Winans (Eds.). Fish Marking Techniques. American Fisheries Society. Symposium 7.

Sampaio, F. A. C., R. L. Ferreira, O. S. Pompeu, H. A. Santos \& M. A. Castro. 2009. Comparação da capacidade natatória de peixes epígeos e hipógeo (Characidae). Anais do III Congresso Latino Americano de Ecologia, 10 a 13 de Setembro de 2009, São Lourenço - MG.

Santos, H. A., P. S. Pompeu \& C. B. Martinez. 2007. Swimming performance of the migratory Neotropical fish Leporinus reinhardti (Characiformes: Anostomidae). Neotropical Ichthyology, 5: 139-146.

Santos, H. A., P. S. Pompeu \& C. B. Martinez. 2007. A Importância do Estudo da Capacidade Natatória de Peixes para a Conservação de Ambientes Aquáticos Neotropicais. Revista Brasileira de Recursos Hídricos, 12: 141-149.

Santos, H. A., P. S. Pompeu, G. S. Vicentini \& C. B. Martinez. 2008. Swimming performance of the freshwater Neotropical fish: Pimelodus maculatus Lacepède, 1803. Brazilian Journal of Biology, 68: 433-439.
Teixeira, A. \& R. M. V. Cortes. 2007. PIT telemetry as a method to study the habitat requirements of fish populations: application to native and stocked trout movements. Hydrobiologia, 582: 171-185.

Tritico, H. M \& A. J. Cotel. 2010. The effects of turbulent eddies on the stability and critical swimming speed of creek chub (Semotilus atromaculatus). The Journal of Experimental Biology, 213: 2284-2293.

Volpato, G. R., R. E. Barreto, A. L. Marcondes, P. S. A. Moreira \& M. F. de B. Ferreira. 2009. Fish ladder selects biological traits in upstream migrating curimbata, Prochilodus lineatus. Marine and Freshwater Behaviour and Physiology, 42: 307-313.

Wildman, L., P. Parasiewicz, C. Katopodis \& U. Dumond. 2002. An Illustrative Handbook on Nature-Like Fishways Summarized Version. 21p. American Rivers, Glastonbury, CT. available from: http://act.americanrivers.org/site/DocServer/ Nature-LikeFishwaysHandbook.pdf?docID=202 (17 May 2011)

Zydlewski, G. B., A. Haro, K. G. Whalen \& S. D. McCormick. 2001. Performance of stationary and portable passive transponder systems for monitoring of fish movements. Journal of Fish Biology, 58: 1471-1475.

Submitted March 24, 2012

Accepted October 1, 2012 